\title{
Chloride Content of Rocky Flats Scrub Alloy Twelfth Campaign Solution Following Head End Treatment
}

by

H. P. Holcomb

E. I. du Pont de Nemours and Company

Savannah River Site

Aiken, South Carolina 29808

\section{INFORMATION ONLY}

\author{
DISCLAIMER
}

\begin{abstract}
This report was prepared as an account of work sponsored by an agency of the United States Government. Neither the United States Gnvernment nor any agency thereof, nor any of their employees, makes any warranty, express or implied, or assumes any legal liability or responsibility for the accuracy, completeness, or usefulness of any information, apparatus, product, or process disclosed, or represents that its use would not infringe privately owned rights. Reference herein to any specific commercial product, process, or service by trade name, trademark, manufacturer, or otherwise does not necessarily constitute or imply its endorsement, recommendation, or favoring by the United States Government or any agency thereof. The views and opinions of authors expressed herein do not necessarily state or reflect those of the United States Government or any agency thereof.
\end{abstract}

\section{DOE Contract No.}

This paper was prepared in connection with work done under the above contract number with the U. S. Department of Energy. By acceptance of this paper, the publisher and/or recipient acknowledges the U.S. Government's right to retain a nonexclusive, royalty-free license in and to any copyright covering this paper, along with the right to reproduce and to authorize others to reproduce all or part of the copyrighted paper. 


\section{DISCLAIMER}

Portions of this document may be illegible in electronic image products. Images are produced from the best available original document. 
$\operatorname{OSR} \operatorname{Ri}^{3}-4 \mathrm{~A}$

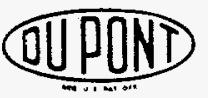

INTER-OFFICE MEMORANDUM

SAVANNAH RIVER PLANT

DPSP $-88-272-85$

August 8,1988

TO :

L. B. CURTIS, 221-F - D. F. CHOSTNER, 221-F

FROM: H. P. HOLCOMB, 772-Fltp

CHLORIDE CONTENT OF ROCKY FLATS SCRUB ALLOY TWELFTH CAMPAIGN SOLUTION FOLLOWING HEAD END TREATMENT

INTRODUCTION AND SUMMARY

A single batch of dissolver solution from the twelfth Rocky Flats Scrub Alloy (RFSA) campaign has been analyzed for chloride content following head end treatment to reduce its concentration. Scrub alloy buttons were dissolved in Tank 6.4D during July. In subsequent head end processing, chloride was precipitated with mercurous ion added as the nitrate. The precipitate, $\mathrm{Hg}_{2} \mathrm{Cl}_{2}$, was coremoved with the gelatin floc via centrifugation.

Duplicate samples from Tank 11.2, containing the head end product, produced excellent agreement between their density measurements and acid analyses, indicating them to be truly representative of the tank's contents. Duplicate aliquots from each of these solutions were analyzed using the turbidimetric chloride method developed in the Separations Technology Laboratory. These resulted in an average chloride value of $53 \mathrm{ppm}(\mu \mathrm{g} / \mathrm{mL})$ chloride for the head end product. Relative standard deviation of the measurement was $\pm 6 \mathrm{ppm}(\mathrm{n}=4)$, a precision of $\pm 11 \%$. Such a variance is normal at this low chloride level. Since initial chloride values prior to head end averaged $1365 \mathrm{ppm}(0.0385 \mathrm{M})$, as analyzed by Laboratories Department, a chloride DF of approximately 26 was obtained. Such a reduced chloride level (to less than $100 \mathrm{ppm}$ ) in the treated solution will permit further canyon processing with minimal corrosion.

\section{EXPER IMENTAL}

Samples Analyzed

A pair of samples from Tank 11.2, designated Laboratories 非 68145 and 非8146, were taken on 8/3. Values for density and acidity 
DPSP $-88-272-85$

L. B. CURTIS - D. F. CHOSTNER

Page 2

August 8,1988

between the samples showed excellent agreement. These samples were therefore considered to be representative. Duplicate aliquots from each sample were analyzed for chloride.

Each of the sample vials, containing approximately $12 \mathrm{~mL}$, measured about $25 \mathrm{mr} / \mathrm{hr}$ at $5 \mathrm{~cm}$ directly over the capped pyramidial vial. Such a low level is a direct benefit of canyon flushing operations to reduce the very high residual activity from Purex operation. The lowered radiation levels are a necessity due to analytical operations requiring hands-on manipulations.

Samples were very clear in appearance and light tannish-brown in color. No solids were noted by Laboratories during their determinations nor were any noted by us.

Analysis of Chloride

The procedurel employed to determine the low values of chloride in the high alpha solutions from Tank 11.2 was also used for all previous RFSA campaigns, except. for the first. A visual turbidity comparison was used for that campaign since our improved method had not been developed.

The newer analytical technique employs an instrumental measurement of turbidity formed when silver ion reacts with residual chloride in the sample aliquots. Sample pretreatment negated interferences by other solution components, principally $\mathrm{Al}+3$ and $\mathrm{Hg}^{+2}$. The latter, in solution, forms a very strong covalent bond with chloride. This compound ionizes only to a very small extent and, without pretreatment, can be the cause of low chloride results from usual analytical procedures.

Standards, prepared in a radioactively cold matrix closely simulating that of the RFSA solution and containing known quantities of chloride, were concurrently analyzed in like manner to provide a working curve of turbidity versus total chloride in solution.

\section{Results}

Individual values obtained for the chloride content of duplicate l-mL aliquots taken from each Tank 11.2 sample solution are shown in Table 1. Also given is the average of the four results, reported as the analysis value, and the relative standard deviation for: the average. 
DPSP $-88-272-85$

L. B. CURTIS - D. F. CHOSTNER

Page 3

August $8, .1988$

TABLE 1

CHLORIDE CONTENT OF RFSA DISSOLVER SOLUTION FOLLOWING HEAD END

$\mathrm{Cl}^{-}$

Batch 7FHERF-1

$\mathrm{ppm}(\mu \mathrm{g} / \mathrm{mL})$

非61845

Aliquot 非 1

60

Aliquot 非 2

51

非1846

Aliquot 非

54

Aliquot 非

45

Average $(n=4)$

53

Rel. Std. Dev.

$6( \pm 11 \%)$

\section{$\underline{\text { DISCUSSION }}$}

Previous work 2 by $R$. S. Ondrejcin at SRL indicated that in order to protect downstream canyon equipment from chloride attack, the chloride content of RFSA solutions should be less than $100 \mathrm{ppm}$. This batch from the 12 th campaign meets that criterion.

Based on Laboratories' value of $1365 \mathrm{ppm}(0.0385 \mathrm{M})$ chloride in the material prior to head end treatment, a $\mathrm{Cl}^{-} \mathrm{DF}$ of 26 was obtained. Table 2 summarizes the chloride content of the solutions, before and after head end treatment, for those RFSA campaigns for which the turbidimetric technique was used to determine chloride following head end treatment. Pairs of numbers represent different batches of the same campaign processed through head end. 
DPSP $-88-272-85$

L. B. CURTIS - D. F. CHOSTNER

Page 4

August 8,1988

\section{TABLE 2}

CHLORIDE REMOVAL SUMMARY FOR RFSA CAMPAIGNS

\begin{tabular}{|c|c|c|c|c|}
\hline $\begin{array}{c}\text { RFSA } \\
\text { Campaign } \\
\end{array}$ & $\begin{array}{c}\text { Date } \\
\text { Dissolved } \\
\end{array}$ & $\begin{array}{l}\text { ppm } \mathrm{Cl}^{-} \text {Prior } \\
\text { to Head End }\end{array}$ & $\begin{array}{l}\text { ppm C1- After } \\
\text { Head End }\end{array}$ & $\begin{array}{c}\text { Chloride } \\
\text { DF }\end{array}$ \\
\hline $2 n d$ & $12 / 84-1 / 85$ & 1600 & 75 & 21 \\
\hline $3 r d$ & $3 / 85$ & 1000 & 23 & 43 \\
\hline $4 \mathrm{th}$ & $9-10 / 85$ & $1890-1235$ & $75-45$ & $25-27$ \\
\hline 5 th & $7 / 86$ & $2930($ Avg) & 62 (Avg) & 47 \\
\hline $6 \mathrm{th}$ & $11 / 86$ & 1525 (Avg) & 74 (Avg) & 21 \\
\hline $7 \mathrm{th}$ & $4-5 / 87$ & $1030-850$ & $39-24$ & $26-35$ \\
\hline $8 \mathrm{th}$ & $11-12 / 87$ & 1240 & .26 & 48 \\
\hline 9 th & $1-2 / 88$ & 1350 & 37 & 36 \\
\hline 10 th & $2 / 88$ & 870 & $28-40$ & $31-22$ \\
\hline l1th & $5 / 88$ & 1455 & 41 & 35 \\
\hline $12 \mathrm{th}$ & $7 / 88$ & 1365 & 53 & 26 \\
\hline
\end{tabular}

These data show that the DF obtained for chloride removal across head end for the 12th campaign is quite acceptable. The quantity of chloride present in the initial dissolver solution has increased to a level approximating those immediately prior to the 10 th campaign. The latter had the second lowest chloride content so far. The 5 th campaign, with a chloride level about twice that of the lith or 12 th, was successfully processed through head end. Therefore, with that buffer, concerns about increasing chloride should continue to be minimal.

\section{REFERENCES}

1. DPSPU-84-272-113, Determination of Low Chloride Values in Rocky Flats Scrub Alloy Solutions and Other Complex Matrices, H. P. Holcomb to J. T. Buckner, Jr:; November 29, 1984.

2. Excerpt from talk, "Corrosion Study for Rocky Flats Scrub Alloy Program", by R. S. Ondrejcin, SRL, Dec. 2, 1983. $\mathrm{HPH} / \mathrm{h}$ 